\title{
MEASURING SMALLHOLDER COMPARATIVE ADVAN- TAGE IN THREE SOUTH AFRICAN PROVINCES
}

\author{
S. Ngqangweni' ${ }^{1}$, J.F. Kirsten ${ }^{2}$, M. Lyne ${ }^{3} \&$ B. Hedden-Dunkhorst ${ }^{4}$
}

A major policy issue in South Africa is the redefinition of the role of the previously disadvantaged smallholder agricultural sector in providing rural livelihoods. This study shows that black small-scale farmers do produce certain agricultural activities both profitably and efficiently. This has major implications for broader rural growth and development. Agricultural policies aimed at promoting commodities that best make use of resources are required to exploit potential linkages with non-agricultural sectors of the economy.

\section{INTRODUCTION AND BACKGROUND}

One of the major policy debates in South Africa concerns how small farmers could be effectively reintegrated into the broader economy. A related issue is how programmes designed to give them access to the market will affect overall rural incomes and employment. Are there any agricultural commodities which small farmers can produce profitably and efficiently? Do small farmers have comparative advantage in any form of agricultural activity or should they rather seek employment outside agriculture? Agricultural research needs to answer these questions in order to facilitate planning towards policies and programmes that will enhance growth and development in poor, previously disadvantaged rural areas. It has been shown in Asia and elsewhere in Africa that competitive smallholder sector activities could act as engines for broader rural economic growth through linkages with other nonagricultural sectors (see inter alia Delgado, Hazell, Hopkins \& Kelly, 1994; Hazell \& Roell, 1983).

This paper presents results of a study conducted among small farmers in the Eastern Cape, KwaZulu-Natal and Northern Province. The objective of the study was to show in which commodities, if any, black small-scale farmers have a comparative advantage. The second of the five sections of this paper describes the research approach employed in the study. In section 3 the

1 Department of Agricultural Economics, Extension and Rural Development, University of Pretoria.

2 Department of Agricultural Economics, Extension and Rural Development, University of Pretoria.

3 Department of Agricultural Economics, University of Natal.

4 Department of Agricultural Economics, University of the North. 
specific commodities and their markets in each province are discussed. Section 4 presents the results of the investigation into comparative advantage in each of the provinces. The final section discusses the results and concludes the paper.

\section{METHODOLOGY}

Specific production activities in each province were chosen in specific small farmer locations for which budgets were drawn. Relevant information from these budgets was extracted into Policy Analysis Matrices (PAMs). A PAM is an accounting tool that organises data on costs of production and marketing for specific activities and market channels (Monke \& Pearson, 1989). In a PAM, observed 'financial' or 'private' and 'economic' or 'social' costs are contrasted. This leads to calculation of economic indicators used to assess economic efficiency and the competitiveness of specific activities in specific markets. The main indicator ratio is the Domestic Resource Cost (DRC) ratio, which reflects the relationship between the true cost of producing one unit of an item and the return to selling it. A DRC ratio of less than 1 is generally taken to indicate efficient production based on the existence of comparative advantage.

Due to a lack of resources, size and diversity of the small farm sector in South Africa, and the absence of reliable secondary data on small farmer production, no attempt was made to study representative farms and activities. In the Eastern Cape a total of 7 budgets were drawn which cover beef, dairy, maize, citrus and cabbage activities. In KwaZulu-Natal 13 budgets covering timber, sugar-cane, maize and dry bean budgets were drawn. A total of 12 budgets (including maize, dry beans, sorghum, cowpeas, groundnuts and bambaranuts) were analysed for the Northern Province. The Northern Province work includes case studies under different cropping systems, namely mono-cropping, inter-cropping and mixed cropping. This provides an additional perspective on comparative advantage analyses in small-scale agriculture.

\section{CASE STUDY COMMODITIES AND MARKETS}

\subsection{Eastern Cape}

Smallholder commercial farming in this province is largely restricted to activity that resulted from parastatal-run irrigation, dryland and livestock projects introduced in the 1970 s as part of a broader strategy to develop the former homeland areas of Transkei and Ciskei (Van Rooyen, 1995). Although 
these farms benefited from the earlier project activities, they have now emerged as independent farmers producing for the market, although some still owe the previous parastatals some money. Due to the recent closure of the parastatals and the limited support services provided by the provincial department of agriculture, some of the farmers are experiencing a drop in agricultural productivity and some are facing severe problems.

The Eastern Cape part of the study drew 7 budgets based on commercial farm activities taking place in the former agricultural project areas in the Mpofu, Keiskammahoek and Zwelitsha districts in the former Ciskei), and Herschel in the former Transkei. These budgets cover indigenous and exotic cattle breeds, dairy, cabbage, citrus, irrigated and dryland maize activities.

Indigenous beef (Nkone) farmers in Mpofu produce for the growing market of abattoir, and abattoir suppliers in the central Eastern Cape region. Production takes place under conducive climatic conditions, good physical capital with both family and hired labour. Exotic cattle (mainly Simmentaler) are reared under generally the same physical and economic conditions as their indigenous counterparts. Dairy production takes place under intensive conditions with irrigated pasture but not much supplementary feeding. Heavy infrastructure investment (e.g. milking parlours) from the earlier project days characterised the dairy farms included in the case study. The below average' milk production is sold locally both fresh and sour.

Citrus is produced in modem mechanised orchards with the main goal of maximising export volumes. The citrus farmers employ hired labour (permanent and seasonal) from surrounding villages, while none of the family members work on the farms. Marketing takes place in an environment free of controls through a local co-operative.

Cabbage production takes place on small irrigated plots, which supply the local market in the nearby urban areas of King Williams Town. Irrigated maize is also produced in small plots, with $75 \%$ of the produce was marketed locally. Dryland maize plots mainly supply crops for fodder, with only $30 \%$ of the produce sold locally.

\subsection{KwaZulu-Natal}

Fieldwork in KwaZulu-Natal was conducted in the Umzumbe district in the coastal region and in the Mpumalanga and Okahlamba districts in the Midlands region. Significant differences between technologies necessitated disaggregation of crops into 13 activities, which included sugar-cane, timber, 
dry beans (with high and low technology options for both single and double crops) and maize (under high, low and subsistence technologies).

Small sugar growers deliver their cane to sugar mills owned by private companies and receive the preferential "A-pool" price. This price is protected from international competition by an import tariff. This protected environment also includes subsidised credit, information and transaction costs (Mbowa, 1996).

Emerging timber growers deliver their product to pulp mills under contract with private forestry companies. The sample farmers do not receive preferential prices but are fully exposed to export prices.

Dry beans are an important food and cash crop in the former KwaZulu homeland. Surplus beans are sold locally and are distinct from imported varieties. Emerging farmers produce two bean crops in the coastal region, whereas in the Midlands region, where the growing season is shorter, many farmers prefer not to double-crop.

Maize is the most important food staple produced in the former KwaZulu (Lyne, 1989). On average, small farm households produce about one-half their maize requirement. Very few $(17 \%)$ are self-sufficient (Nieuwoudt \& Vink, 1989). Generally, three classes of technology are identified, namely those who apply chemicals (high technology), those who do not (low technology), and subsistence production.

\subsection{Northern Province}

Of the three study provinces, the Northern Province has the most difficult environment for smallholder agriculture. It is generally semi-arid and densely populated in arable areas, and also close to bordering countries where the opportunity cost of agricultural labour is much lower than in South Africa.

The study in the Northern Province was mainly based on small, mainly subsistence producers in the former Venda and Lebowa homelands. Only about $5 \%$ of these producers produce for the market. Fieldwork for this part of the study was conducted in the Bochum and Sekgosese districts. Six most important crop enterprises in each of the two districts were selected for drawing up enterprise budgets, namely maize, sorghum, cowpeas, dry beans, groundnuts and bambaranuts. 
The next section presents a summary of the results of the study on comparative advantage in the three provinces.

\section{RESULTS OF COMPARATIVE ADVANTAGE ANALYSIS}

Table 1 summarises the analysis of comparative advantage by province. It lists the DRC and other indicator ratios of economic efficiency.

Table 1: Economic efficiency indicators by region

\begin{tabular}{|c|c|c|c|c|c|c|}
\hline Crop and Region & DRC & NPCO & NPCI & EPC & $\overline{P C}$ & SRP \\
\hline \multicolumn{7}{|l|}{ KwaZulu } \\
\hline Sugar-cane: Coast & 0.77 & 1.2327 & 1.1400 & 1.2453 & 2.1564 & 0.2283 \\
\hline Sugar-cane: Midlands & 0.83 & 1.4033 & 1.1399 & 1.4367 & 3.9914 & 0.4410 \\
\hline Timber: Coast & 0.39 & 1 & 1.1398 & 0.9921 & 1.0550 & 0.0319 \\
\hline Timber: Midlands & 0.34 & 1 & 1.1398 & 0.9930 & 1.0453 & 0.0284 \\
\hline Dry Beans - High Technology: Coast & 0.50 & 1.0030 & 1.1400 & 0.8207 & 0.7159 & -0.0614 \\
\hline Dry Beans - Low Technology: Coast & 0.54 & 1.0030 & 1.1400 & 0.8200 & 0.6956 & -0.0596 \\
\hline $\begin{array}{l}\text { Dry Beans - High Technology (Double } \\
\text { Crop): Midlands }\end{array}$ & 0.64 & 1.0030 & 1.1400 & 0.8545 & 0.6558 & -0.0596 \\
\hline $\begin{array}{l}\text { Dry Beans - High Technology (Single Crop): } \\
\text { Midlands }\end{array}$ & 0.61 & 1.0030 & 1.1399 & 0.8825 & 0.8611 & -0.0284 \\
\hline $\begin{array}{l}\text { Dry Beans - Low Technology (Double } \\
\text { Crop): Midlands }\end{array}$ & 0.70 & 1.0030 & 1.1400 & 0.8577 & 0.6096 & -0.0577 \\
\hline $\begin{array}{l}\text { Dry Beans - Low Technology (Single Crop): } \\
\text { Midlands }\end{array}$ & 0.69 & 1.0030 & 1.1399 & 0.8825 & $0.8 \overline{576}$ & -0.0238 \\
\hline $\begin{array}{l}\text { Maize - High Technology (Emerging } \\
\text { Farmer): Midlands }\end{array}$ & 0.58 & 1 & 1.1399 & 0.8873 & 0.8037 & -0.0462 \\
\hline $\begin{array}{l}\text { Maize - Low Technology (Emerging } \\
\text { Farmer): Midlands }\end{array}$ & 0.64 & $\overline{1}$ & 1.1399 & 0.8818 & 0.7629 & -0.0462 \\
\hline Maize (Subsistence Farmer): Midlands & 0.65 & 1 & 1.1399 & 0.9256 & 0.9427 & -0.0132 \\
\hline \multicolumn{7}{|l|}{ Eastern Cape } \\
\hline Indigenous cattle: Mpofu & 0.57 & 1 & 1.14 & 0.98 & 0.43 & -0.02 \\
\hline Exotic cattle: Mpofu & 1.11 & 1 & 1.14 & 0.88 & 2.38 & -0.07 \\
\hline Dairy: Keiskammahoek & 0.73 & 1 & 1.14 & 0.82 & 1.36 & 0.04 \\
\hline Irrigated citrus: Mpofu & 0.65 & 1 & 0.47 & 1.33 & 0.00 & 0.17 \\
\hline Irrigated cabbage: Zwelitsha & 0.83 & 1 & 1.14 & 0.75 & 3.01 & 0.12 \\
\hline Irrigated maize: Keiskammahoek & 0.35 & 1 & 1.14 & 0.91 & 1.17 & 0.07 \\
\hline Dryland maize: Herschel & 0.35 & 1 & 1.14 & 0.97 & 1.01 & 0.01 \\
\hline \multicolumn{7}{|l|}{ Northem Province } \\
\hline Maize: Bochum & 0.35 & 1 & 1.14 & 1.00 & 1.04 & 0.02 \\
\hline Sorghum: Bochum & 0.25 & 1 & 1.14 & 1.00 & 1.02 & 0.02 \\
\hline Cowpea: Bochum & 0.27 & 1 & 1.14 & 0.99 & 1.03 & 0.02 \\
\hline Dry Bears: Bochum & 0.27 & 1 & 1.14 & 0.99 & 1.03 & 0.02 \\
\hline Sorghum/Bambaranut: Bochum & 0.21 & 1 & 1.14 & 1.00 & 1.02 & 0.02 \\
\hline Sorghum/Cowpea: Bochum & 0.19 & 1 & $\overline{1.14}$ & 1.00 & 1.02 & 0.01 \\
\hline Maize: Mamaila & 0.74 & 1 & 1.14 & 0.97 & 0.85 & -0.03 \\
\hline Dry Beans: Mamaila & 0.83 & 1 & 1.14 & 1.00 & 0.92 & -0.01 \\
\hline Maize/Cowpea: Mamaila & 0.65 & 1 & 1.14 & 0.98 & 0.91 & -0.03 \\
\hline Maize/Cowpea/Groundnut: Mamaila & 0.53 & 1 & 1.14 & 0.99 & 0.97 & -0.01 \\
\hline Maize/Bambaranut/Groundnut: Mamaila & 0.44 & 1 & 1.14 & 0.99 & 0.98 & -0.01 \\
\hline Maize/Groundnut: Mamaila & 0.37 & 1 & 1.14 & 0.98 & 0.96 & -0.02 \\
\hline
\end{tabular}




\subsection{Definition of indicator ratios}

The NPCO (nominal protection coefficient on inputs) indicates the extent to which the market price differs from the social price. The NPCI (nominal protection coefficient on inputs) is the ratio of the private price of inputs to their social price. The EPC (effective protection coefficient) measures the effects of policies that affect the markets for outputs and tradable inputs. The PC (profitability coefficient) is the ratio of the profit obtained from an activity measured with private prices to that measured with social prices.

\subsection{Interpretation of results: caveats}

Four caveats should be borne in mind in interpreting these results. First, the local marketing costs may be very high on a per unit basis, as a result of which markets may be thinly traded, generating output price information that cannot be applied realistically to a major expansion of local production. Many commodities behave like non-tradables. Major increases in local production will overwhelm the local market.

Second, land rental is constrained by prevailing institutional arrangements. The arrangements are such that emerging farmers are unable to increase the scale of their operation, reducing average transaction costs and strengthening their incentive to produce a marketable surplus. Because of these institutional arrangements, the opportunity costs (or shadow prices) applied to factors such as land may not reflect their true market value if institutional arrangements were liberalised. For enterprises where land accounts for a large share of total revenue (e.g. timber in KwaZulu, and all enterprises studied in the Northern Province), this probably leads to DRCs that are "too low" in some cases.

Third, the methodology used is a partial equilibrium approach. Sensitivity analyses need to be done to test the effects of major changes affecting prices and resource valuations.

Fourth, the opportunity costs specified reflect the present situations where the highest alternative for returns to labour and capital are outside agriculture. Therefore, positive outcomes for smallholder farms studied do not imply that other modes of agricultural production (for example similar activities on large-scale farms) offer less comparative advantage. 


\section{DISCUSSION AND CONCLUSIONS}

Many of the DRCs estimated for smallholder tradable commodities are smaller than 0.60 , suggesting real opportunities to exploit the comparative advantage enjoyed by emerging farmers. In the Eastern Cape case study, possibilities point towards indigenous cattle and citrus in particular. However, the case study on indigenous cattle illustrated the need to keep fixed costs low in order to draw advantage from the adaptation of the Nkone breed to the local environment. Citrus also presents special opportunities along river valleys where there is abundant water and good soils. One of the factors llul could potentially lessen these opportunities is probably the recurring need for reinvestment in new orchards replacing ageing ones. This would require the borrowing of considerable loan capital amounts which could place heavy debt burdens, as it has been observed among some of the case study farmers.

The cases from KwaZulu-Natal arguably benefited from the highest agricultural potential of the three provinces included in this study. KwaZuluNatal pioneered contractual relationships between processors and outgrowers to accommodate smallholder cash cropping, particularly in the timber and sugar-cane industries. These two activities, along with dry beans and maize, show a good comparative advantage. However, maize and dry beans are nontradables in the study area. The small local market will limit the strong local profitability they demonstrate.

Overall, smallholder agriculture appears to offer opportunities for the efficient use of land, labour and capital in the Northern Province. However, small-scale agriculture is barely commercial in the areas studied. The main instances of smallholder cropping observed for the present study were primarily for home use. Therefore, the DRCs observed were primarily for non-tradable activities and, thus, do not really indicate comparative advantage for commercial purposes. In addition, the efficiency results are largely driven by the fact that land and labour observed in the study area had a relatively low opportunity cost. Most farmers were retired persons or women left behind when young men left on migration. If labour were costed at full migration wage, the DRCs would be much higher. Further work in competitiveness area needs to focus on marketing costs for other activities which are visibly beginning to pick up, such as poultry and horticultural products produced under small-scale irrigation.

A general conclusion that could be drawn from this study is that black smallholders in South Africa can produce certain activities both profitably and 
efficiently. These opportunities have previously not been exposed. This has significant implications for rural income and employment growth. If these apparent advantages could be exploited, this would mean more opportunities for growth in the broader rural economy through linkages with agriculture. However, more research is required to establish the sustainability of observed opportunities.

\section{REFERENCES}

DELGADO, C.L., HAZELL, P.B.R., HOPKINS, J., \& KELLY, V. (1994). Promoting inter-sectoral growth linkages in rural Africa through agricultural technology and policy reform. Am. J. Agr. Econ, 76 (5):1166-71.

HAZELL, P.B.R. \& ROELL, A. (1983). Rural growth linkages: Household expenditure patterns in Malaysia and Nigeria. Washington, DC: IFPRI.

LYNE, M.C. (1989). Distortion of incentives for farm households in KwaZulu. Unpublished PhD Dissertation, Pietermaritzburg: University of Natal.

MBOWA, S. (1996). Farm size and economic efficiency in sugar-cane production in KwaZulu-Natal. Unpublished PhD Dissertation, Pietermaritzburg: University of Natal.

MONKE, E.A. \& PEARSON, S.R. (1989). The policy analysis matrix for agricultural development. Ithaca: Cornell University Press.

NGQANGWENI, S.S., LYNE, M.C., HEDDEN-DUNKHORST, B., KIRSTEN, J.F., DELGADO, C.L. \& SIMBI, T. (1997). Indicators of Competitiveness of South African Smallholder Farmers in Selected Activities. Unpublished Land and Agricultural Policy (LAPC) Report, Johannesburg.

NIEUWOUDT, W.L. \& VINK, N. (1989). The Effects of Increased Earnings From Traditional Agriculture in Southern Africa. South African Journal of Economics, 57:257-69.

VAN ROOYEN, C.J. (1995). Overview of DBSA's Farmer Support Programme, 1987-93. In R. Singini and C.J. van Rooyen (eds), Serving Small-Scale Farmers: An Evaluation of the DBSA's Farmer Support Programmes. pp. 1-21. Halfway House: Development Bank of Southern Africa. 